Volume 8, No.1.1, 2019

International Journal of Advanced Trends in Computer Science and Engineering

Available Online at http://www.warse.org/IJATCSE/static/pdf/file/ijatcse1081.12019.pdf

https://doi.org/10.30534/ijatcse/2019/1081.12019

\title{
Towards a New Critical Role of Information Systems in the Modern Decision Making Process
}

\author{
Lile Ramona \\ Management Department \\ Aurel Vlaicu University \\ Revolutiei 77, Arad, Romania \\ ramonalile@yahoo.com \\ Andrei-Mihai Luchian, Elena-Corina Boscoianu, \\ Robotics and Mechatronics Dept., Transilvania University Brasov, \\ B-dul Eroilor nr. 29, Brasov, Romania \\ Mircea Boscoianu \\ Translivania University of Brasov \\ Faculty of Engineering Technology and Industrial Management \\ B-dul Eroilor nr. 29, Brasov, Romania \\ mircea_boscoianu@yahoo.co.uk \\ Victor Vladareanu*, \\ Robotics and Mechatronics Dept. \\ Institute of Solid Mechanics of the Romanian Academy \\ Bucharest, 010141, Romania \\ victor.vladareanu@ vipro.edu.ro
}

\begin{abstract}
In modern society, information systems have come to be seen as an essential key for businesses and organizations. It has become essential in decision making for managers. The application of information systems opened new decision making possibilities for management and organization. The purpose of this paper is to present the role of information systems in decision making management and how managers could make use of such a possibility. It start by identifying the functions of management, the role of management and continues with the usage of the three levels of decision making. The following paper provides a framework of the use of information systems generally, but also an idea about the downgrade that still exists in the system and that is that the director/CEO still has the final decision even after the manager studies and takes the best decision.
\end{abstract}

Keywords: Decision Making, Information, Information Systems, Management Roles And Functions.

\section{INTRODUCTION}

The transition from industrial to information society made a great impact on economic, social and culture aspects of life. Nowadays there are few aspects which remain unaffected by information technology. In the last years, the information society became crucial and changed the way of economy and business [1, 16-18]. Being conducted in a global environment, a business could not be done without any computer based information. We have evolved into the information era due to the new technology and the use of information systems. This helped managers in decision making and changed the way businesses due to the low rate in uncertainty.

Most specialty authors would agree that the information era changed and keeps changing all types of organizations, regardless of their size and importance. The new technology era became a tool that improves management, by using the information to take a decision. [1], [5] Also information systems provide an increased competitive advantage for any organization. Although information systems affected decision making, there are also other domains that were affected by it. Still there are few studies that examined the role of information in decision making management. Information systems for decision management could be described into two general categories: systems that help people analyze a situation, the decision being taken by the superior and systems make a recommendation concerning the action that should be taken by the superior [4, 22-24].

The study about frameworks of information will help us by offering data regarding the uncertainty of decisions. Furthermore, since the study refers to understand the role of information systems, we could also use it to help us understand how information systems support major components and decision making functions [7, 25-28]. These systems are important to managers at lower or operational levels since they receive the most aid, being able to withstand any well-structured problem for which a $\mathrm{CEO} /$ director/manager is responsible.

Over time people intended to provide a better understanding for the roles and functions of management and offered a different 
approach about information systems, especially for the organization of decision making functions.

In the following chapter we will present the functions of managerial roles, management and the description of information systems and the three level decision making platforms. In the end of the paper we will provide a suggestion about information systems, with the intention of changing the idea of some managers. There is much work to be done in broadening the impact of information systems in the modern world.

\section{MANAGEMENT ROLES AND FUNCTIONS}

The information which is supposed to help support managers cannot be applied in any type of organization as long as the leaders have not establish what their goals is and how do they desire to accomplish it.

A person who gets the job done is a manager, but we clearly need to distinguish the task of managers and functions of management. As a manager, a person may perform a diversity of activities such as accounting, selling, surveillance, etc. These actions are also called task and are not functions. Actions and activities are performed through managerial functions which go back to the early 1920 [1], [2], [5] In the 1920, managers performed the following functions: planning, directing, controlling, organize. (Figure.1)

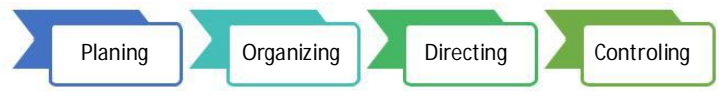

Figure 1: Management functions

Management process has four functions and is executed through a series of decisions. These decisions are taken by each management function. An organization function is a mean by which a human co-ordinates an efficient production of services through human resources, money, assets and time.

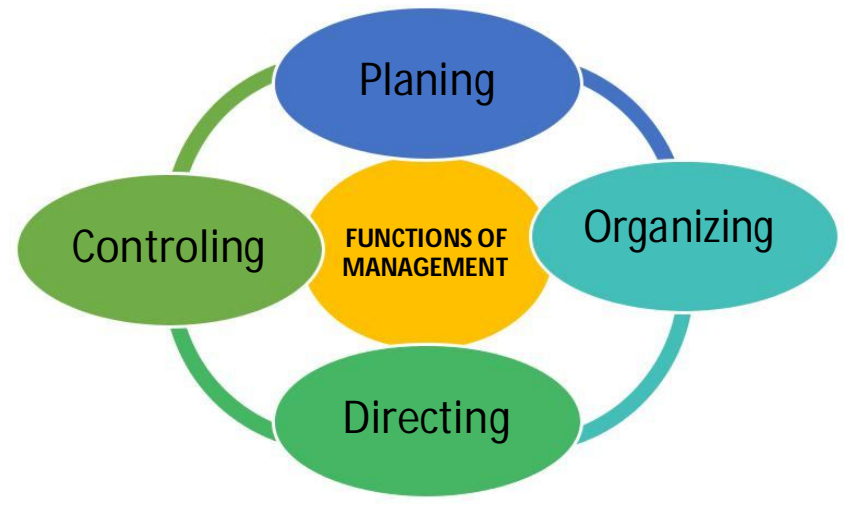

Figure 2: Management functions and tasks

The most well-known function of management is directing/ motivating, which requires a large amount of knowledge and practice. The control function is the last stage which completes the cycle of management [3].
In figure 2, we will observe a summary of functions and tasks for management goals, development, strategies and tactics. Group and individuals differ in their thinking and decisions. Knowing these differences, certain people are assigned with responsibilities over an individual or group. Lead by motivation and communication, the managers evaluate and adjust the performance of organizations. As a tool information systems can support these functions.

The activity of a manager is described and characterized by his/her decision, which is a critical function. For a manager to take a decision, he/she must follow a variety of functions. Information systems are necessary when organizations grow. They are performed by people that can be removed from their daily activities. Manager's attention increased rapidly in time, with a small pattern. When a problem appears all other matters must be suspended until it is solved.

As a conclusion, there is no time for a manager to get deeply involved in a variety of issues. Studies show that a manager's day is full of tasks limited by time and devoted to each individual. Over time, research studies shown that managers relied on the verbal information more that formal information. [3], [4] As shown in the past managers have three separate roles: informational, decisional and interpersonal. These roles can be supported in various degrees. For a manager to adopt a certain role, he/she must have access to the required information. His role is directly affected by his attitude and involvement in coordinating a task to his/her subordinates. In informational roles a managers gathers and shares a large quantity of information with his/her subordinate team. The final decision includes the opinion of the entrepreneur, thus the manager must adopt the project to what the director decides.

\section{A DECISION MAKING PROCESS PARADIGM BASED ON INFORMATIONAL SYSTEMS}

The evolution of technology has increased the changes in economy, organizations and businesses. Usually, information was supposed to be used as an operational function. The emergence of information goes back to 1950 where it was just a simple accounting transaction. The technology revolution made data more accessible, it organized information more efficiently and started to provide reports that lately were used for decision making, thus it became a tool for management support. Nowadays, information systems are more complex than they were back in the 1970 , when the emphasis was only operational. [14, 15, 37, 38].

In time information systems reduced the uncertainty in decisions and in the mid 1980 it became known as management information systems, which was referred to a full computer based information system. Thus, from its conventional function in operational support, it became a tool for tactic and strategic support. This new role was highlighted in more studies. External data must be converted into suitable information for all types of managers/team leaders so that they fulfill their responsibilities.

This is the best example of how to use information and get quick results without large cost of time. Today, information is a mean to gather, process, store, use and disseminates data [34-36, 39]. Still 
Lile Ramona, et al., International Journal of Advanced Trends in Computer Science and Engineering, 8(1.1), 2019,48 - 53

even after all this evolution managers need complete and correct correct information to fully assess all the variables, so that the advanced as for an take has the smallest percentage of failure. their choice or no relevant information is considered to be vital in positive one. (Figure.4).

All the talk about improving decision making management is number assumption. Normally the aim of information systems is to produce data so that a person may take action and if possible to facilitate decision making. (Figure.3)

Still, even with all this information and data that makes the task of a manager easier, there is still no evolution regarding the final decision of management. Here we have the CEO, who is the final decision maker, the one that decides which course of action to take into consideration [5].

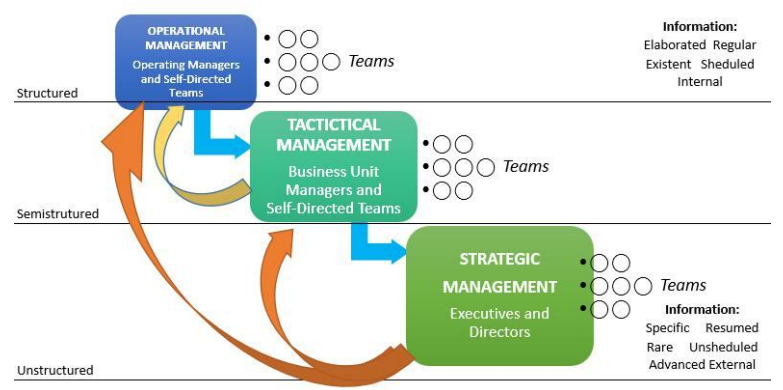

Figure.3: Decision Making Management

Although the manager studied and analyzed the information, so he/she can take the lowest risk decision, the director/CEO can always ignore him/her and take whatever decision he seems fit. Thus, there are two types of decisions: programmed and un-programmed.

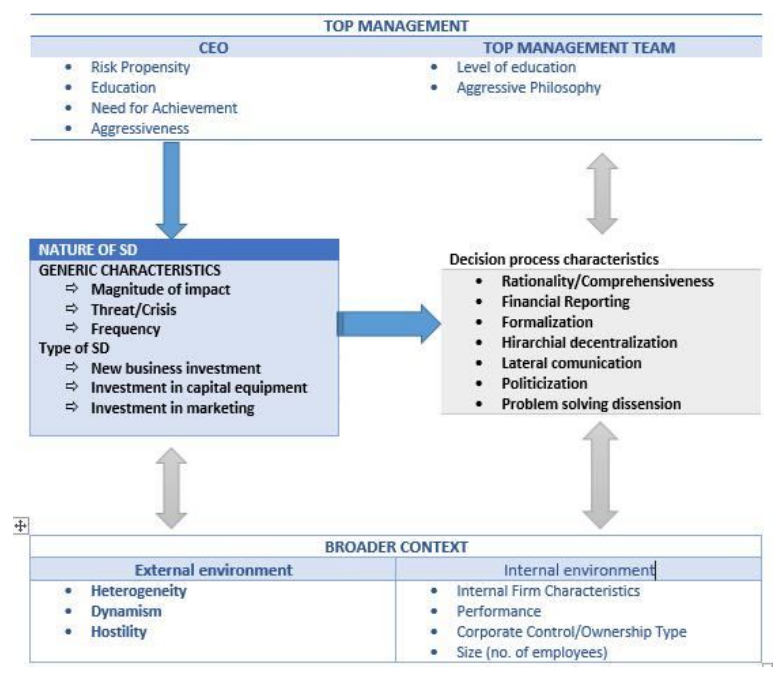

Figure.4: - Factors Influencing Strategic Decision Making Processes
For a programmed decision, we have all the variables decision they and accurate, thus making the best choice in Accurate, fast andun-programmed they have no data sustain improving the solution to try to turn the decision into a competitive advantages of businesses and organizations. $[4,5]$

\section{THE ROLE OF CONTEXT IN STRATEGIC DECISION MAKING}

In Research over time has influenced the strategic decision making process, in an attempt to provide an example. The following categories influenced the strategic processes: manager's individual character and dynamics and internal organization context. In addition to the text, research should integrate the role and significance of nature in the shaping process.

An integration with such contextual domains will offer a wide framework, promising new research domains. Such a framework must combine the following perspectives: "an individual decision perspective", strategic or management choice", "firm characteristics and resources which are available" and "environmental determinism".

\subsection{Decision perspective}

Research has shown us that various stimulus may be interpreted differently by managers in different organizations or even in same office. The way managers categorize and label a decision is influenced by the organizations subsequent responses. If a decision is perceived as a crisis, a different action will be taken so that the decision would become an opportunity. Still, our knowledge on decision making processes is still quite limited. Most work forces focus on: single decision characteristics or identification and diagnosis of early stage issues [12].

\subsection{The perspective of management choice}

From this point of view we can see that by stressing the strategic choice, we shall soon determine the strategy content and process due to the contending of strategic leader or top managers.

This study refers specifically to the top management of a company on corporate strategies, performance and on formality planning. There has been few improvements and little empirical work on the link between top management and the process of making strategic decisions.

A study made by Stein point out the fact that leadership does not constitute a meaningful contextual domain influencing strategic procedures.

This issue must be solved empirically Still the influence of leaders on strategic decisions remains unclear [13].

\subsection{Competitive strategic management}

Explanations and definitions until now have considered one organization, namely, dynamic balance between it and its external environment. In reality, organizations are in a constant competition, which strongly influence the management and organizational behavior. Consider, for example, an automobile factory. Its long-term success depends not only on achieving a dynamic balance between its management and 
political, economic, social and cultural side, but also competition from other car companies do in the area. This competition can be controlled to some extent by a series of protectionist policies, but it cannot be removed.

However, in conditions of globalization of economic activities, competition between car manufacturers in scale generated tremendous pressure on each competitor. Strategic management of each improvement strategy implemented a value that will lose the competitive advantage obtained fairly quickly.

Developing and implementing a strategy involves taking a risk. For an investor, the risk is there given the uncertainty over economic gains or losses associated with certain investments. If considered several possible investments with comparable values of investment risk, they are called middle-income revenues. Getting these revenues is to reach more organizations or investor, which makes them believe media. They do not represent mathematical results, but the most probable values for some investment will be accepted. A intelligent competitor creator can develop and implement a strategy at the same level of risk with other possible strategies, and could generate additional revenue. They are called above average income and give the organization a competitive strategy advantage compared to other competing organizations. Designed in time, this organization confers competitive advantage [10].

In this competitive context, strategic management is the management process through which an organization achieve strategic competitiveness and above average income. This includes the above definitions based on strategic thinking and respectively the development and implementation of strategies. Application areas.

Strategic management has developed potent mediator of conflict or competition in the survival and the success of an organization depends on achieving a dynamic balance between internal forces and external organization and respectively achieving competitiveness policy in relation to other interface between a university and social environment, economic and political where there is a dynamic equilibrium.

This dynamic equilibrium is, in fact, one of the strategic objectives of the reform process of our higher education. Resizing function of universities leads to the idea that they are bidding service to society and as such, they are in competition with other providers of educational services and knowledge to obtain financial and human resources necessary for optimum performance. Universities must develop an entrepreneurial behavior and strategic management able to make its strategic competitiveness. Warwick Universities of Twente in the Netherlands and the UK are significant examples of entrepreneurial universities, with undeniable results achieved by implementing strategic management [11].

\section{ALIGNMENT OF THE MISSION WITH THE STRATEGIC DECISION MAKING PROCESS}

The mission of an organization is the reason and creates value for society. It summarizes existential law and explains her vision of the organization. The mission determines the evolution of the organization in the sense of turning vision into reality. In

the vision of an ideal state expresses possible programmatic mission expresses an evolution towards this state. The vision focuses on the internal image of the organization and aspirations of top management, while mission focuses on the external image of the organization and the determinants or management decision makers. In short, the mission of an organization communicates what the organization is and what she wants to do for this company [15].

A better formulation of the mission of an organization should include three important elements:

- An overall expression of the vision

It aims to achieve this excellence by stimulating domestic intellectual climate for both students and teachers, a climate that is sensitive to national and international needs. University recognizes the need for efficient management of all its resources, no matter where they come from [8], [9].

The strategic plan of the Open University (The Open University) in the UK, for 1998-2006, formulated the following mission: "The Open University is:

- Open in relation to people - offering free admission to higher education for a broad and diverse segment of students and playing a leading role in meeting the needs of continuing education;

- open spaces in relation to education - providing educational opportunities for adults in their place of work or at home, whether they remain in the same locality or traveling while studying in Europe or other regions of the world;

- Open in relation to methods - using specific methods and developing distance education, including new information technologies to improve the efficiency of learning and students' homes to reach them wherever they are;

- Open in relation to ideas - is a vibrant academic community dedicated expansion, progress and knowledge sharing [6].

\section{CONSIDERATIONS REGARDING DATA ANALYSIS}

Looking over the variables involved, it can be provided one of the best regression equations [7]

In theory, the number of SDs may be involved in choosing the limit of the variables that forms the full equation model or the regression equation model, since the absence of this limit can't give the validation of true results. After deriving both of these models, the results are closely the same. However, talking about the cases with a larger amount of differences, the solution includes evaluation by adding or removing variables form the equation, so the final result approached the real value, indicating the best model. 
On the other hand, multi-collinearity is another possible problem, so more procedures were tested by calculating condition indexes to discover the warning level [12].

Also rationality is a factor of the volatility of decision-specific characteristics, comparing to the insignificant influence of the management and environment factors. Dean and Sharfman (1993a) and Stein (1980) developed the idea that the magnitude impact of a decision is one of the most significant agent in decision-making variables, since the management takes much more attention when consequences are involved in the rationality $[4,13]$.

\section{CONCLUSION}

In the 21 century, information systems are a part of modern organization, which supports management activities. Management has four functions that require information support and data requires three different levels of decision making to support the level. Even though the use of information gives power to managers, there are not enough studies to fully trust the given information. Along with the evolution of technology, the strategic management could substitute at any time for tactical management, thus showing that any CEO can do what a manager can do and a manager could do what a CEO can do. Still there is no full thrust for a manager, the CEO making the final decision, even though the manager studied a lot of information for that decision. Still, information systems made a great contribution to the organization department, managers understanding more and more information about their tasks and taking the lowest risky decision that they could possibly take. In the future, due to information systems we could see a manager that could make a final decision, even if it is crucial for the survival of the business.

The data for decision making will challenging and problematic, depending on the situation acquired, respecting different types of information that could be attributed to the bureaucratic mechanisms. The central hypothesis is that special departments create special databases that keeps all the values from the previous decisions and will be used in certain situation to see if the problem from now matches or look similar to the one encountered in the past.

For further development and effectiveness, an organization must not wait for an information analysis, but must act, actually it is required that they do so. This way decision will be made based on studies and fact that even had results, good or bad ones, but still there will be advantage on how a manager should "play the game".

\section{ACKNOWLEDGMENT}

This work was developed with the support of MENUEFISCDI, project MASIM, PN-II-PT-PCCA-2013-4-1349, $2014-2017$.

\section{REFERENCES}

[1] Bocij, P.;Chaffrey,D.;Greasley,A. and Hickie,S.:'Business Information

Systems, Technology, Development and Management for the e-business", 2nd Edition, England, 2003.
[2] Combs,R.M.: "Information Systems for Business Management", Pitman Publishing, Great Britain, 1995.

[3] Crawford,I.M.:"Marketing Research and Information Systems", [http://www.fao.org/docrep/W3241E/w3241e0a.htm], 1997

[4] Dean, J.W. Jr., and M.P. Sharfman, "Procedural Rationality in the Strategic Decision Making Process", Journal of Management Studies, (1993a) https://doi.org/10.1111/j.1467-486.1993.tb00317.x

[5] Gordon, B.D.\& Olson, M.H. : "Management Information Systems, Conceptual Foundations, Structure and Development", 2nd Edition, McGraw Hill Book Co, USA, 1985

[6] Gorry,G. \& Scott Morton, M.: "A framework for Management Information Systems", Management Review, Vol.49, 1989

[7] Haag, S.; Baltzan, P. and Philips, A.: "Business Driven

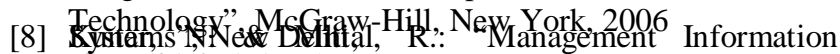
ISBN-81-261-1675-7. URL: [http://www.booksgoogle.com/books/], 2006

[9] Lucey,T.:"Management Information Systems", 9th Edition, Thompson Learning, London, 2005

[10] Porter, M.E., Millar, V.E.: "How information gives you competitive advantage", Harvard Business Review, 1985

[11] Smart, C., and I. Vertinsky, "Strategy and theEnvironment: A Study of Corporate Responsesto Crises", Strategic Management Journal, 1984 https://doi.org/10.1002/smj.4250050302

[12] Smith, K.G., M.J. Gannon, C. Grimm, and Mitchell T.R., "Decision Making Behavior in Smaller Entrepreneurial and Larger Professionally Managed Firms", Journal of Business Venturing, 1988 https://doi.org/10.1016/0883-9026(88)90016-X

[13] Stein, J., Contextual Influence on Strategic Decision Methods, University of Pennsylvania, PhD dissertation, 1980

[14] Tannenbaum, A.S., "Control in Organizations", McGrawHill, New York, 1968.

[15] Wally, S., and R.J. Baum, "Personal and Structural Determinants of the Pace of Strategic Decision Making", Academy of Management Journal, (1994)

[16] Ivascu, L, Cioca, LI, Opportunity Risk: Integrated Approach to Risk

Management for Creating Enterprise Opportunities, in: Proc International Conference on Psychology, Management and Social Science (PMSS) CHINA 2014

[17] Boșcoianu, M., Prelipcean, G., Mihalcea, M., Sima, M, An econometric framework for determining the influences of socio economic activities on natural environment, Metalurgia International, vol XV (2010), Special Issue 1/2010, ISSN 1582-2214

[18] Victor Vladareanua, Radu I. Munteanub, Ali Mumtazc, Florentin

Smarandached and Luige Vladareanua , "The optimization of intelligent control interfaces using Versatile Intelligent Portable Robot Platform", Procedia Computer Science 65 (2015): 225 - 232, ELSEVIER, www.sciencedirect.com, doi:10.1016/j.procs.2015.09.115. https://doi.org/10.1016/j.procs.2015.09.115 
[19] Cononovici, Sergiu Boris. "A Sensor-Based Reactive Behaviour Obtained by Learning for a Mobile Robot." Proceedings of the Annual Symposium of the Institute of Solid Mechanics, May. 2005.

[20] Vlădăreanu, Victor, et al. "Intelligent extended control of the walking robot motion." Advanced Mechatronic Systems (ICAMechS), 2014 International Conference on. IEEE, 2014.

[21] Y.F. Feng, H.B. Wang, T.T. Lu, et al. "Teaching training method of a lower limb rehabilitation robot." Int J Adv Robot Syst, vol. 13, pp. 1-11, February 2016. https://doi.org/10.5772/62058

[22] Smarandache F., Vladareanu L., "Applications of Neutrosophic Logic to Robotics - An Introduction", The 2011 IEEE International Conference on Granular Computing Kaohsiung, Taiwan, Nov. 8-10, 2011, pp. 607-612, ISBN 978-1-4577-0370-6 https://doi.org/10.1109/GRC.2011.6122666

[23] Şandru Ovidiu Ilie, LuigeVladareanu, Paul Şchiopu, Victor Vlădareanu, Alexandra Şandru, "Multidimensional Extenics Theory”, U.P.B. Sci. Bull., Series A, Vol. 75, Iss. 1, 2013, pg.3-12, ISSN 1223-7027

[24] Capitanu, L; Vladareanu, L; Onisoru, J; Iarovici, A ; Tiganesteanu, C; Dima, M, Mathematical model and artificial knee joints wear control, Journal of the Balkan Tribological Association, Volume: 14 Issue: 1 Pages: 87101 Published: 2008, WOS:000255409400010, ISSN: $1310-4772$

[25] Cononovici, S.B., Vlădăreanu, V., et al. "Control Strategies for Synchronous Generation of Resistive Loads Correlated to the Robot Motion Environment", $5^{\text {th }}$ International Workshop on Cyber Physical Systems (IWoCPS-2016), Romanian Academy, Bucharest.

[26] Vladareanu Luige, et all, Method and device for the realtime control of robots by virtual projection, EPO: A 2008 00232.

[27] Vladareanu, Luige; Sandru, Ovidiu I.; Velea, Lucian M.; $\mathrm{Yu}, \mathrm{Yu}$, Hongnian), Actuator Control In Continuous Flux Using Winer Filters, Proceedings of The Romanian Academy Series A-Mathematics Physics Technical Sciences Information Science, Volume:10 Issue: 1 Pages: 81-90 Published: JAN-APR 2009, WOS:000264992200011, ISSN: 1454-9069.

[28] O. Formsma, N. Dijkshoorn, S. van Noort and A. Visser (2011), "Realistic Simulation of Laser Range Finder Behavior in a Smoky Environment", in "RoboCup 2010: Robot Soccer World Cup XIV", Lecture Notes on Artificial Intelligence series, volume 6556, p. 336-349, Springer, Heidelberg, March 2011. https://doi.org/10.1007/978-3-642-20217-9_29

[29] Cioca, M., Cioca, L.I, Duta, L., Web Technologies and Multi-criteria Analysis Used in Enterprise Integration in Studies In Informatics And Control Volume: 20 Issue: 2 Pages: 129-134 Published: JUN 2011

[30] Boșcoianu, M., Prelipcean, G., The creation of flexible special purpose vehicles (PPP-Equity-Fund) architectures for stimulating the innovative SMEs, The 7th International Conference on Business Excellence, 2012

[31] Strom, Johannes, Slavov, George, Chown, Eric, Omnidirectional Walking Using ZMP and Preview Control for the NAO Humanoid Robot, RoboCup 2009:
Robot Soccer World Cup XIII, SN: 978-3-642-11875-3, 2010.

[32] L.Vladareanu, A.Curaj, R.I.Munteanu, Complex Walking Robot Kinematics Analysis And PLC Multi-Tasking Control, Revue Roumaine des Sciences Techniques Série Électrotechnique et Énergétique, 2011, 10 pag.), Volume: 57 Issue: 1 Pages: 90-99 Published: JAN-MAR 2012, WOS:000303096800010, ISSN 0035-4066.

V Vasile; Vasile, I; Nistor, A; Vladareanu, L; Pantazica, M ; Caldararu, F; Bonea, A; Drumea, A; Plotog, I, Real Time Control Open Systems of 5 DOF NanoManipulators, Advanced Topics In Optoelectronics, Microelectronics, And Nanotechnologies V, Proceedings of SPIE-The International Society for Optical Engineering Volume: 7821, Article Number: 78211W DOI: 10.1117/12.882156 Published: 2010, WOS:000287803900067, pg. 7821-42, 2010, ISSN 0277$786 \mathrm{X}$.

[33] Yi Dong, Hongnian Yu, Feng Gao, Design, modelling and control of a light touch Mechanism, International Conference on Advanced Mechatronic Systems, Zhengzhou, China, 11-13 August 2011.

[34] Athanasia Louloudi, Ahmed Mosallam, Naresh Marturi, Pieter Janse and Victor Hernandez, Integration of the Humanoid Robot Nao inside a Smart Home: A Case Study, School of Science and Technology Örebro University, Sweden 701 82, 2010.

[35] Vladareanu L., Vladareanu V., Schiopu P., „Hybrid ForcePosition Dynamic Control of the Robots Using Fuzzy Applications", 3-th Edition of the IEEE/IACSIT International conference on Biomechanics, Neurorehabilitation, Mechanical Engineering, Manufacturing Systems, Robotics and Aerospace, ICMERA2012, Bucharest, 26-28 October 2012, pp.8, Invited Paper https://doi.org/10.4028/www.scientific.net/AMM.245.15

[36] Prelipcean, G., Boșcoianu, M., Aspects regarding the impact of the "Rabla" program and the "Casa Verde" program on the ecological consumption in Romania, Amfiteatrul Economic Journal vol 14(31), 2012, pp.25-37

[37] Prelipcean, G., Boșcoianu, M. , A hybrid framework for SME financing based on the mix between governmental support and the use of a specialized investment fund in the actual context of a slow recovery after crises and turbulences, in Procedia Economics and Finance vol 15 2014 pp 738- 745 https://doi.org/10.1016/S2212-5671(14)00445-6

[38] Yang Liu, Hongnian $\mathrm{Yu}$ and Luige Vladareanu,An Iterative Learning Control Scheme for the Capsubot, UKACC International Conference on Control 2008, University of Manchester, UK, 2-4 September 2008 